\title{
The Paradigm Shift in the Indian Education System during COVID19: Impact, Opportunities and Trends
}

\author{
Sidhi Menon $\mathrm{U}^{1}$ and Manu Vasudevan $\mathrm{Unni}^{2}$ \\ ${ }^{1}$ Student-BBA, Department of Management, St. Claret College, Bangalore University, INDIA \\ ${ }^{2}$ Researcher, Toulouse School of Management, University Toulouse 1 Capitole, Toulouse, FRANCE \\ ${ }^{1}$ Corresponding Author: sidhiumenon@gmail.com
}

\begin{abstract}
The COVID-19 pandemic is a huge challenge to education systems. Education is the main priority direction and main development indicator in all civilized countries of the world. The COVID-19 global pandemic has upended all the education system across the world. In this time of crisis, a well-rounded and effective educational practice is what is needed for the capacity-building of young minds. It will develop skills that will drive their employability, productivity, health, and well-being in the decades to come, and ensure the overall progress of India. This research paper tries to investigate on the various impact of Covid-19 in education system especially on rural India. We also try to throw light on the different existing and new initiatives by government during the pandemic. The novel coronavirus has transformed the centuries-old, chalk-talk teaching model to one driven by technology. The last 50 years have seen huge growth worldwide in the provision of education at all levels. COVID-19 is the greatest challenge that these expanded national education systems have ever faced. Many governments have ordered institutions to cease face-to-face instruction for most of their students, requiring them to switch, almost overnight, to online teaching and virtual education. We see a drastic rise in the use of various teaching and conferencing technologies which has been explained in this paper, also various advantages and disadvantages to the students in the use of these technologies have been covered in this research paper by identifying opportunities and trends. Finally research has been concluded by providing avenues to future research and a meaningful conclusion.
\end{abstract}

Keywords-- Education System, COVID-19, Pandemic, India, Crisis, Impact, Trends, Opportunities, Government Initiatives, Digital Technology, AI

\section{INTRODUCTION}

Armed conflicts, forced displacement, climate change induced disasters and protracted crisis have disrupted the education of 75 million children and youth globally. And that number is growing in an unprecedented way with the spread of COVID-19 (CoronaVirus2019). ${ }^{1-5}$ Education has been hit particularly hard by the COVID-19 pandemic with 1.53 billion learners out of schooland 184 country-wide school closures, impacting $87.6 \%$ of the world's total enrolled learners. Drop-out rates across the globe are likely to rise

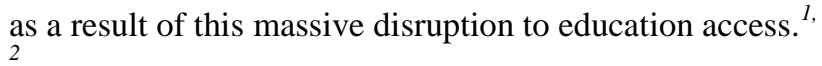

Second week of March 2020, state governments across India began shutting down schools and colleges temporarily as a measure to contain the spread of the novel coronavirus. It's close to three months and there is no certainty when they will reopen. ${ }^{2}$ This is a crucial time for the education sector-board examinations, nursery school admissions, entrance tests of various universities and competitive examinations, among others, are all held during this period. ${ }^{2} \mathrm{Few}$ states have planned to conduct exams with all the precautionary measures, there is an uncertainty and fear among students. As the days pass by with no immediate solution to stop the outbreak of Covid19, school and university closures will not only have a short-term impact on the continuity of learning for more than 285 million young learners in India but also engender far-reaching economic and societal consequences. $^{2}$

The global pandemic has taken a massive hit on all the sectors of the economy. While it has been slightly easier for MNCs and professionals to adopt work from home as the new normal and continue business as usual, the times have been challenging for the education system around the world. With disruptions everywhere, several concerned scholars, citizens, politicians, and bureaucrats support the need for reimagining and reinventing the education system. $^{3}$

A key aspect of coping with Covid-19 is to ensure that services are being delivered to whatever extent possible. While for professionals across industries it has been an easier transition as many of them work on their laptops and smart devices even in office. They can simply plug in at homes now. ${ }^{4}$ of course, what is missing is face to face, personal communication which will get restored as and when things are back to normal. But students have had to make far bigger adjustments as learning has always been in classrooms which they can't go to now. Besides many of them may not be that well equipped with technology tools to avail of remote learning. Here the Digital India vision of the government is emerging as a vital instrument for solving the present crisis due to Covid-19.Hence, comes in the smart classroom systems. ${ }^{4}$

Education, as a result, has largely moved online. The World Economic Forum reports a surge in the use of language apps, virtual tutoring, video conferencing tools, 
and online learning software in the last three months. India, too, is witnessing an e-learning boom. Classes on Zoom, WhatsApp and Skype are becoming the norm for students, parents and teachers. ${ }^{5}$ Though these new age online interactive classes are being the modern form of education, amidst these new forms there is an high rise of fear among the parents and students on the privacy concerns of using online virtual interactive applications. One such familiar case was Zoom App, Zoom has been criticised for a range of privacy issues, including sending user data to Facebook, wrongly claiming the app had endto-end encryption, and allowing meeting hosts to track attendees. ${ }^{13,}{ }^{14}$ Such issues are also one of the worst challenges to be tackled.

The adoption of smart classroom systems by schools is transforming the traditional education system. The sudden switch is not only limited to private schools but even a number of government schools have started running smart classes. Though the crisis is devastating, it is making our schools and even colleges, technologically advanced.Virtual classrooms and various online tools are helping to continue and enhance the engagement between the teacher and students as close to the classroom type experience.The government quickly recommended shifting to "online teaching," this ignores India's immense digital divide — with embedded gender and class divides. This research paper throws light into the various shifts in Indian Education System during COVID19 pandemic. It deep dives into explaining the impact, opportunities and trends in education system. This paper also enlightens research impact on rural Indian education system and also various existing and new initiatives by government during pandemic. Finally, the research paper end with few conclusions, limitations and future research.

\section{IMPACT OF COVID 19 ON EDUCATION SYSTEM}

The COVID-19 pandemic has affected educational systems worldwide, leading to the near-total closures of schools, universities and colleges. As of 22 May 2020, approximately 1.725 billion learnersare currently affected due to school closures in response to the pandemic. According to UNICEF monitoring, 153 countries are currently implementing nationwide closures and 24 are implementing local closures, impacting about 98.6 percent of the world's student population. 10 countries' schools are currently open. School closures impact not only students, teachers, and families, but have far-reaching economic and societal consequences School closures in response to the pandemic have shed light on various social and economic issues, including student debt, digital learning, food insecurity, and homelessness, as well as access to childcare, health care, housing internet, and disability services. The impact was more severe for disadvantaged children and their families, causing interrupted learning, compromised nutrition, childcare problems, and consequent economic cost to families who could not work. ${ }^{6}$

\section{Schools}

Going to school is the best public policy tool available to raise skills. While school time can be fun and can raise social skills and social awareness, from an economic point of view the primary point of being in school is that it increases a child's ability. Even a relatively short time in school does this; even a relatively short period of missed school will have consequences for skill growth. ${ }^{6}$

\section{Families}

Families are central to education and are widely agreed to provide major inputs into a child's learning. (Bjorklund and Salvanes,2011) ${ }^{15}$. The current globalscale expansion in home schooling might at first thought be seen quite positively, as likely to be effective. But typically, this role is seen as a complement to the input from school. Parents supplement a child's maths learning by practising counting or highlighting simple maths problems in everyday life; or they illuminate history lessons with trips to important monuments or museums. Being the prime driver of learning, even in conjunction with online materials, is a different question; and while many parents round the world do successfully school their children at home, this seems unlikely to generalise over the whole population. So while global home schooling will surely produce some inspirational moments, some angry moments, some fun moments and some frustrated moments, it seems very unlikely that it will on average replace the learning lost from school. But the bigger point is this: there will likely be substantial disparities between families in the extent to which they can help their children learn. Key differences include (Oreopoulos et al. 2006) ${ }^{16}$ the amount of time available to devote to teaching, the non-cognitive skills of the parents, resources (for example, not everyone will have the kit to access the best online material), and also the amount of knowledge - it's hard to help your child learn something that you may not understand yourself. Consequently, this episode will lead to an increase in the inequality of human capital growth for the affected cohorts. ${ }^{6}$

\section{Assessments}

Internal assessments are perhaps thought to be less important and many have been simply cancelled. But their point is to give information about the child's progress for families and teachers. The loss of this information delays the recognition of both high potential and learning difficulties and can have harmful long-term consequences for the child.

In higher education many universities and colleges are replacing traditional exams with online assessment tools. This is a new area for both teachers and students, and assessments will likely have larger measurement error than usual. Research shows that employers use educational credentials such as degree classifications and grade point averages to sort applicants (Piopiunik et al. 2020) ${ }^{17}$. The increase in the noise of the applicants' signals will therefore potentially reduce the 
matching efficiency for new graduates on the labour market, who might experience slower earnings growth and higher job separation rates. This is costly both to the individual and also to society as a whole (Fredriksson et al. 2018) ${ }^{18}$.

\section{Graduates}

The careers of this year's university graduates may be severely affected by the COVID-19 pandemic. They have experienced major teaching interruptions in the final part of their studies, they are experiencing major interruptions in their assessments, and finally they are likely to graduate at the beginning of a major global recession. Evidence suggests that poor market conditions at labour market entry cause workers to accept lower paid jobs, and that this has permanent effects for the careers of some. The graduates from programmes with high predicted earnings can compensate for their poor starting point through both within- and across-firm earnings gains, but graduates from other programmes have been found to experience permanent earnings losses from graduating in a recession (Oreopoulos et al., 2012) ${ }^{19}$.

\section{Unintended Strain on Health Care}

Women make up almost $70 \%$ of the health care workforce, exposing them to a greater risk of infection.They often cannot attend work because of childcare obligations that result from school closures. This means that many medical professionals are not at the facilities where they are most needed during a health crisis.

\section{Unequal Access to Technology}

Lack of access to technology or fast, reliable internet access can prevent students in rural areas and from disadvantaged families. Lack of access to technology or good internet connectivity is an obstacle to continued learning, especially for students from disadvantaged families. In response to school closures caused by COVID-19, UNESCO recommends the use of distance learning programmes and open educational applications and platforms that schools and teachers can use to reach learners remotely and limit the disruption of education.

\section{Childcare}

School closures puts a strain on parents and guardians to provide childcare and manage distance learning while children are out of school. In the absence of alternative options, working parents often leave children alone when schools close and this can lead to risky behaviours, including increased influence of peer pressure and substance abuse

\section{Nutrition and Food Insecurity}

Nutrition plays a critical role in cognitive development and academic performance for children. Many children worldwide rely on free or discounted meals at schools. When schools close, nutrition is especially compromised for children in schools where food is provided.

\section{Sluggish Cross-Border Movement of Students}

Universities in many countries such as Australia, UK, New Zealand, and Canada are highly dependent on the movement of students from China and India. It is becoming clearer that this cross-border movement of students will take a beating at least for the next two to three years and will lead to a major financial risk for universities in these countries who are already under financial pressure. ${ }^{24}$

\section{Passive Learning by Students}

The sudden shift to online learning without any planning especially in countries like India where the backbone for online learning was not ready and the curriculum was not designed for such a format has created the risk of most of our students becoming passive learners and they seem to be losing interest due to low levels of attention span, added to this is that we may be leaving a large proportion of the student population untouched due to the digital divide that is part of many developing nations including India. We are now beginning to realize that online learning could be dull as it is creating a new set of passive learners which can pose new challenges. ${ }^{10}$

\section{Unprepared Teachers for Online Education}

Online learning is a special kind of methodology and not all teachers are good at it or at least not all of them were ready for this sudden transition from face to face learning to online learning. Thus, most of the teachers are just conducting lectures on video platforms such as Zoom which may not be real online learning in the absence of a dedicated online platform specifically designed for the purpose. There is a risk that in such a situation, learning outcomes may not be achieved and it may be only resulting in engaging the students. ${ }^{10}$

\section{Changing Format of Student Recruitment}

Universities and colleges worldwide are facing a major risk in the area of student recruitment and retention. The risk of losing students is so high that they will need to re-look at their admission practices, admission criteria and the overall recruitment process itself which will include, new methods of outreach and application process itself. ${ }^{10}$

\section{Children and Youth with Disabilities}

Along with other marginalized populations, including children from minority groups, are neglected in the best of times and have lower educational outcomes than their peers.

\section{IMPACT ON RURAL INDIA}

In India, 320 million students have been affected by COVID-19 school closures, and though the government quickly recommended shifting to "online teaching," this ignores India's immense digital dividewith embedded gender and class divides. The 2017-18 National Sample Survey reported only 23.8 percent of Indian households had internet access. In rural households (66 percent of the population), only 14.9 percent had access, and in urban households only 42 percent had access. And males are the primary users: 16 percent of women had access to mobile internet, 
compared to 36 percent of men. Young people's access is even less: A recent news report stated only 12.5 percent of students had access to smartphones. Furthermore, most teachers are ill-equipped for online teaching. There is a high peak to violence and exploitation: When schools shut down, early marriages increase, more children are recruited into militias, sexual exploitation of girls and young women rises, teenage pregnancies become more common, and child labour grows. ${ }^{11}$

\section{Digital Divide}

Even though internet-based teaching is the most appropriate stop-gap arrangement now, it has highlighted the inequalities in the education system. A majority of the student population is being left out in the pursuit of basic education.

Rural schools are relying on the most basic internet application WhatsApp, to connect to their students. Across many districts in rural India, school teachers have been asked to make WhatsApp group of all parents in their respective classes and send them lessons that children can learn at home. This was the simplest tool teachers in rural and semi-urban regions could use. Teachers are taking help from the central government's digital learning portal DIKSHA, which has lessons in multiple languages for all classes from primary to senior secondary. Some teachers are also making videos for practical concepts like teaching photosynthesis or geometry. These videos are then shared on the WhatsApp groups to connect to their students, but not to all. While teachers have been enthusiastic in preparing lessons and circulating through WhatsApp groups, they are only able to reach out to a section of their students.

About 9,000 students from poor families are enrolled in various municipal schools in Amravati, capital of Andhra Pradesh. Of these, just over 2,500 have access to android phones. That's a mere 27 percent. Without access to any form of smartphone or internet, 73 percent of municipal school students in Amravati and a similar large percentage in other municipal and government schools across the country, are missing out on their education during the lockdown.

The rural schools were in their final term when the lockdown came into effect. While a majority of the year's curriculum was completed, the month of March and April are used to revise concepts and introduce students to newer subjects that will be part of the next year's curriculum. These are important to bridge the gaps found in learning levels in government schools, where more often than not students of different age groups and grades study in the same classroom.

Majority of students in rural schools come from minority communities and their learning is not at grade level. The school runs learning camps in the month of May and June for slow learners. "If schools reopen, they will have to do extra hours from July for students of learning camp and even those who are missing out now because they do not have access to WhatsApp. It is difficult to teach new concepts online and most of students are not able to access the videos being sent.
Patchy internet connectivity is adding to the challenge. Internet connectivity is a major hurdle in rural areas like his. Only 36 percent of the Indian population, about 385 million above the age of 12, has access to the internet, according to the India Internet 2019 report by IAMAI and Nielsen. However, the access is not uniform with just 27 percent in rural areas and 51 percent in urban areas getting access to the internet. WhatsApp has over 400 million subscribers in India, the majority in urban parts of the country.

\section{Dependence on Parents}

Parents who are daily wagers and most often uneducated themselves are finding it difficult to manage their children's studies at home. Parents are regularly called to remind about their child's exercises. Some parents are receptive, some others don't pay much attention. Few parents were enthusiastic about WhatsApp lessons, but they couldn't assist their children in studies.

According to the NSSO survey of 2017-18, nearly 45 percent of India's population above 15 years of age is either illiterate or has just attended formal primary education. In rural India, almost 70 percent of people above 15 years of age are either "not-literate" or have education only till middle school. This section may not have the required level of education to teach their children at home.

The hours spent in school makes for better learning. The concentration and involvement in the classroom are different. Now the teachers cannot even assess the learning level. When schools open a lot of students will be lagging in their learning, though the best is being done to keep the continuity in the education. ${ }^{12}$

\section{INITIATIVES BY INDIAN GOVERNMENT}

Looking at this challenge of colleges and schools being shut, government of India, as well as state governments and private players have regularly been publishing information on various initiatives undertaken by ministries like MHRD, Department of Technical Education, NCERT and others to support and benefit youth/students. These initiatives were in place years ago and few new initiatives has also emerged. These initiatives came in handy during the current pandemic situation.

A few of the initiatives are SWAYAM online courses for teachers, DIKSHA PORTAL- will serve as National Digital Infrastructure for Teachers. All teachers across nation will be equipped with advanced digital technology.UG/PG MOOCs for non-technology courses, e-PG Pathshala or e-content containing modules on social science, arts, fine arts, natural and mathematical science, CEC-UGC YouTube channel, Vidwan - a database of experts who provide information to peers and prospective collaborators, NEAT - an initiative by AICTE based on the PPP model to enhance the employability skill among students, in collaboration with Education Technology 
Companies and National Digital Library (NDL), a repository of learning resources with single window facility. Many noteworthy initiatives have been taken up like Spoken Tutorial, Free and Open Source Software for Education (FOSSEE), e-Yantra, Google Classroom and so on.

Special TV channels will be started for the students of the country. Under this proposal, one dedicated TV channel per class from class 1 to class 12 will be started for students to study online. This has been launched under a comprehensive initiative called Pradhan Mantri e-VIDYA. Radio, community radio and CBSE podcast 'ShikshaVani' will be widely used to make education more accessible. Special e-content for visually impaired and hearing impaired children, developed on a digitally accessible information system and learning material for disabled children in sign language has been made available on the NIOS website and YouTube.

It is fact that the government of India as well state governments, through their various ministries/departments, have created infrastructure to deliver e-education. These include National Knowledge Network (NKN), National Project on Technology Enhanced Learning (NPTEL), National Mission on Education through Information and Communication Technology (NMEICT), National Academic Depository (NAD), among others. All these enhance our ability to connect easily with institutions and enhance our access to learning resources. For instance, NKN provides high speed network backbone to educational institutes in India. The online assessment agencies/private business houses are also improving the product, considering the limited bandwidth and social distancing, by managing remotely proctored examinations/skilling assessments. Basic requirements like sturdy education delivery platforms, IT infrastructure, PC/Desktop/Mobile for end-delivery and assessment tools.

\section{OPPORTUNITIES FOR EDUCATION DURING THE COVID-19 PANDEMIC}

The rapid spread of coronavirus disease 2019 (COVID-19) around the globe has necessitated implementation of social distancing measures to slow disease dissemination and conserve personal protective equipment. These actions have changed how we live and work. The COVID-19 pandemic has challenged our mission to teach the next generation. In this moment, we have been dealt new obstacles, which demand flexible solutions. Many schools, colleges and universities across India is having education on a virtual platform. ${ }^{20}$

During this international disaster, some may ask, why bother with education? The duration of this pandemic is unknown, and delays in reengineering education may result in long-lasting deficits in training of students. Virtual education can establish a sense of camaraderie and connection when many are experiencing social isolation. Recent technologies have made virtual education accessible to all training programs. Highquality camera technologies and high-speed Internet have made group-meeting software a feasible replacement for traditional learning experiences. It's important to ensure that these technologies supplement rather than distract from the fundamental goals of teaching, which are to help students gain knowledge, improve critical thinking, and facilitate healthy learning environment. Meaningful learning is not easy, and the present circumstances have transformed students into new learners and have adapted to novel ways of education. ${ }^{20}$

As school after school shuts down in the face of the Covid-19 crisis (in now more than 150 countries), digital learning has risen from a nice-to-have extracurricular facility to become the lifeline for education. But the opportunities that digital technologies offer go well beyond a stop-gap solution during the crisis. Digital technology allows us to find entirely new answers to what people learn, how people learn, where people learn and when they learn. Technology can enable teachers and students to access specialised materials well beyond textbooks, in multiple formats and in ways that can bridge time and space. Alongside great teachers, intelligent digital learning systems cannot just teach us science, but they can simultaneously observe how we study, how we learn science, the kind of tasks and thinking that interest us, and the kind of problems that we find boring or difficult. The systems can then adapt the learning experience to suit our personal learning style with far greater granularity and precision than any traditional classroom setting possibly can. Similarly, virtual laboratories give us the opportunity to design, conduct and learn from experiments, rather than just learning about them.

That being said, the Covid-19 crisis strikes at a point when most education systems are not ready for the world of digital learning opportunities. According to a study (PISA), little more than two-thirds of 15-year-old students in OECD countries are enrolled in schools where digital devices have sufficient computing capacity, and even in a technologically advanced country such as Japan, just $40 \%$ of 15 -year-old students are in schools with adequate software for learning. On average across OECD countries, just about half of 15-year-olds are in schools with an effective online learning support platform, and two-thirds in schools where principals consider that their teachers have the necessary technical and pedagogical skills to integrate digital devices in instruction. ${ }^{20}$

This structure, inherited from the industrial model of work, makes change in a fastmoving world that is vulnerable to disruptions and crises far too slow. The changes in our societies have vastly outpaced the structural capacity of our current education systems to respond. Even the best education minister can no longer do justice to the needs of millions of students, hundreds of thousands of teachers and tens of thousands of schools. The challenge is to build on the expertise of our teachers 
and school leaders and enlist them in the design of superior policies and practices. This is not accomplished just by letting a thousand flowers bloom; it requires a carefully crafted enabling environment that can unleash teachers' and schools' ingenuity and build capacity for change. It requires innovators who challenge institutional structures that too often are built around the interests and habits of educators and administrators rather than learners, innovators who are sincere about social change, imaginative in policy making, and capable of using the trust they earn to deliver effective reforms.

\section{TRENDS IN EDUCATION SYSTEM: POST COVID-19}

"A school is not paradise. But school is a place where paradise can be created" it continued in the same vein as the thought "The classroom with all its limitations, remains a location of great possibility".

In the past few weeks we have a gradual change from classrooms to Zoom or Google Meet - pedagogy to 'panicgogy'. As we track future trends, we will address both myths, and realities, in the new emerging scenario. Suffice it to say that academic schedules have been radically disrupted, most students outside the metro-based middle class have limited computer access, Wi-Fi is kind of spotty and erratic, there is a lot of electricity outage and synchronous virtual classes are very stressful for teachers not used to working with technology. ${ }^{21}$ However, since there are not many options for the time being, the education bulwark so used to brick-and-mortar face-toface interactions, is trying its best to adjust and adapt to the new normal. Many new learnings, new perspectives, new trends will emerge as we head into The Great Unknown:

Fewer kids will go back to school when schools reopen: Denmark eased its coronavirus lockdown on 14th April, by reopening schools and day care centres, but concerns they might become breeding grounds for a second wave of cases convinced thousands of parents to keep their children at home. There is actually a Facebook group called 'My kid is not going to be a Guinea Pig' with 40,000 members in a country as small as Denmark. An overwhelming number of parents are asking the inevitable question, 'Why should my little child go outside first' especially since the virus is still to be brought under leash. India is going to be no different. A lot of well-heeled middle class folks may prefer to delay the return of their kids to school or college. And of course, with so many livelihoods lost, many poor parents may not be able to in any case afford sending their offspring's back to school for a long time. This can also be the case in India.

Fewer kids will go out of town, far from home, to study: The nightmare of kids stuck in Kota, Rajasthan, having to be rescued and brought back home is still fresh in the minds of most parents. Till the situation settles down somewhat, most parents will prefer to find workable alternatives closer home. Competitive exams are surely important, but safety of the young ones will take higher priority till the virus shows at least a visible downward trajectory.

Fewer kids will go overseas to study: Every form of international education is currently affected by the crisis and will be for some time, from study abroad schemes to staff exchanges and internships to transnational collaborative programmes. Universities have been closed and/or are delivering all education online. Every international conference in higher education has been cancelled or turned into a series of webinars. As governments are starting to reopen society and restart business, universities will also gradually reopen their campuses. Nevertheless, new modes of social distancing will continue to apply for quite some time, affecting oncampus learning in physical spaces, from the (international) classroom to libraries and on-campus student networking places. In the short term, international student mobility will decrease, including possible problems with student visas. International visiting professors could teach their courses online, continuing to provide some 'internationalisation at home'. Once travel bans are lifted, in the medium term, student mobility will resume as it has so much become the DNA of contemporary higher education.

Social distancing, little or no sports: The fist-bump, the high-five, the warm handshake, the hug will be gone for a long time. The personal greeting, the smile, the intimacy, the bonhomie have all been subtracted from the class of tomorrow. The class will go from social to asocial. Friendships, social networking, campus bonding and huddles will be on hold for a while. Invisible walls will come up, diluting in many ways the fun \& euphoria of campus life.

Sports too will be in low gear for a while. Gyms, swimming pools, maybe even tracks \& fields will remain shut for some time more. And when they do open, competitive sports and tournaments will take even longer to be reinstated.

Two shift or three shift schools: The need for social distancing will mean lesser students in each class. So the need for most educational institutions to perhaps work two shifts, maybe even three, every day. While this will put infinite more pressure on the teaching and administrative staff, it may actually be a boon in disguise for the taught. Lots of schools and colleges in India have far too many students packed into small classrooms. A sparser class may actually make for better teaching and class interaction. $^{23}$

Social distance may lead to some getting 'socially distant': As it is, equality in the classroom has always been a fiction. The inequality, sadly, will only widen in the days to come. Caste/family background, social status, economic well-being, the kind of school you attended has invariably shaped the student's confidence to speak-up in class. The underprivileged would most likely always be the meek attendees who would feel afraid to say something wrong in class, hence would prefer silence 
over participation. Such inequities do exist. The classroom, with equal seating, with uniform chairs, kind of brought an unsaid democracy to teaching. Technology which allows one student to access class from an airconditioned, hi-speed wi-fi home, while another may be trying to find a quiet corner in an overcrowded tenement with jumpy internet will further 'socially distance' the class. Now, that is surely not what was intended from social distancing!

Teaching versus learning, will need figuring: Oscar Wilde once said, "Education is an admirable thing, but it is well to remember from time to time that nothing that is worth learning can be taught". Going forward, the role of the teacher will get redefined. The notion of a teacher or an educator as the knowledge-holder who imparts wisdom to pupils is no longer fit for the purpose of the future. With students being able to gain access to knowledge, and even learn many a technical skill, through a few clicks on their phones, tablets and computers, we will need to redefine the role of the teacher in the classroom of tomorrow. This may mean that the role of teachers will need to move towards facilitating young people's development as contributing (and employable) members of society, rather than just lecturing. ${ }^{22}$

Teaching will go tech: But just Zoom isn't e-learning. To enable remote learning, technology will kick in big time. The mechanics of remote instruction, however, are not necessarily inclusive or equitable. Remote instruction requires that students have access to both capable computing technology and reliable internet service (and in our country perennial electricity too). Which is not always unfortunately guaranteed in India. Also, Zoom deployment in itself isn't going to equal learning. There will be need to do more. There are already educationists working on taking a lot of science lessons, even geography, to 3-D. A detailed world map in 3-D, for example, for a Class 6 student would surely be so much more fun. Also, a 3-D view of the heart. Technology will enrich teaching, but for that teachers and technologists both will have to persevere and innovate. Technology in education alone will not be the enabler: If you want to see a true crisis in education, one has to look at our government-run schools, or at least the remote ones where a young teacher in an isolated village who has only received perhaps a basic college degree tries to teach $60+$ children in a dilapidated, multi-grade classroom where books are scarce and many of the students (and even more of their parents) are often functionally illiterate. While talk in some elevated places of learning, at Harvard or even our own IIT/IIMs, may be about how new technologies can help transform education, in India it will first have to be about how such tools can help education systems function at a basic level. Change is on the way but those in pivotal positions will have to ensure that its benefits percolate to the benefit of all.

Technology will be about the content, not the container: It is possible to become so enamoured with the technology that insufficient attention is then given to how to use whatever devices are eventually deployed to their full effect. As we move to a greater proliferation of devices, combined with the fact that we will be accessing more content from multiple places, a greater value will be placed on the content, and how that content is used, rather than on any one particular device. Viewed from this perspective, the future of education is in the 'content', not the 'container'. It's about more than just content, of course -- it's also about the connections and the communities (students collaborating with each other, teachers supporting other teachers) that technologies can help enable, catalyse and support as well in the future. A lighter school bag may become a reality: On an average, an Indian school kid carries somewhere between 3-8 kilograms of weight every day to school, depending on the age and the class he/she is studying in. In addition to the books and notebooks, they carry a lunchbox and a water bottle. Digitization and technology may help in shedding some of this weight.

Homework too may move increasingly onto the net. It was already beginning to happen at the better quality schools. Expect it to become more ubiquitous. It may take time. But it will happen for sure.

FOBA and Bulldozer Parents will intensify: Generation $\mathrm{Z}$ in our colleges and Universities today, is a generation that has grown up in a truly globalized and connected world. These Gen Z, 25 years old or less, faced with cancelled exams, shortened school terms, postponed sporting events and even delayed graduations will be troubled by both FOBA (Fear of Being Alone) and FOMO (Fear of Missing Out). Education in the days ahead will have to address the loneliness of remote learning as well as the distress of lost opportunities. We will also see emergence of more protective, more pushy 'Bulldozer Parents' who will try to propel Generation Alpha (Gen A) -- the children of current millennial parents - moving all obstacles out of their way to create a clear path for their 'entitled' kids, making out as if nothing really has happened in the world around us. Blended learning \& personalized education: There will be, going forward, a great opportunity to develop new forms of blended education (that will be in much demand). 'Pre crisis' there was already a growing demand for more flexible and blended forms of lifelong learning beyond initial education in order to address the need to up skill and reskill for the digital economy. Mature adult learners in the future will be more and more interested in micro-credentials which allow them to acquire specific knowledge and skills. The demand will be for more work relevant courses or learning paths and learning experiences that prepare students for AI, AR, VR, ML, Block chain, Big Data, Cloud, data analytics, voice deployment and more. We will see a significant thrust towards experiential learning too. We will see the emergence of top-of-the-line Master Class formats taught by best-in-domain in every field, digitally delivered. A lot of this will be self-learning, that too self-motivated and self-funded. Adult learners will 
also spend more on 'passion' learning - hobbies or skills they always wanted to acquire but had no time for. With lesser travel, lesser likely socializing, and greater workfrom-home, there will be more time for such learning indulgences. ${ }^{23}$

Student debt crisis: This is more pronounced in the West. In India too lots of students (more their parents) are taking education loans. If the employment market does not pick up, student debt could become a serious issue. Reskilling \& Up skilling will gain momentum: Often during recessions, enrolment in higher education surges as more people lose their jobs and/or face a lack of job prospects. Even those employed often see economy downsides as an opportunity to enrol back in school if they were already in lower-paying jobs. Those graduating might also want to stay back in school to get a post graduate degree like was seen in the Great Recession. Courses to be pursued will surely be in technology; but vocational courses may also see a significant uptick. Except that colleges and Universities are not geared to cater to these domains, and the private sector is mostly opportunistic, shallow and expensive.

AI will personalise learning: The opportunities and challenge that the introduction of artificial intelligence (AI) could bring to higher education are significant. Today's colleges and universities face a wide range of challenges, including disengaged students, high dropout rates, and the ineffectiveness of a traditional "one-size-fits-all" approach to education. But when big data analytics and artificial intelligence are used correctly, personalized learning experiences can be created, which may in turn help to resolve some of these challenges. With a personalized learning experience, every student would enjoy a completely unique educational approach that's fully tailored to his or her individual abilities and needs. This could directly increase students' motivation and reduce their likelihood of dropping out. It could also offer professors a better understanding of each student's learning process, which could enable them to teach more effectively. ${ }^{23}$ Artificial Intelligence (AI) \& Cloud Computing will enable MOOC: MOOC - massive open online courses empower teachers and students in remote areas to learn and furnish themselves with the latest knowledge. While a definitive objective is mass customization, different applications and projects will help this grow in reach and impact. Tutoring applications will be modified, with their lesson structures relying upon the execution of a one of a kind user profile. Increased data crunching will make testing an increasingly interactive marvel. AI and machine learning will be used to outline a student's qualities and shortcomings. Individual learning rates and records will be contemplated and computed. These tests, intended to support students' confidence in zones they exceed expectations in and challenge them in regions they don't will become holistic methodologies to enables students to stay encouraged and motivated. Examination \& grading will undergo a change: AI will help teachers deal with assessment, evaluating, paper setting, making mark-sheets and tracking the performance of each student with less tedium. With these tasks made simple they will be able to concentrate more on course improvement, teaching quality and aptitude development. Artificial intelligence frameworks will also move examinations, and scoring sytems, to go increasingly digital with the role, and discretion, of the examiner reducing.

Chatbots will provide personalized help and guidance: Recently, The University of Murcia in Spain began testing an AI-enabled chatbot to answer students' questions about the campus and areas of study. As this chatbot was rolled out, the school's administrators were surprised to discover that it was able to answer more than 38,708 questions, answering correctly more than $91 \%$ of the time. Not only was this chatbot able to provide immediate answers to students outside of regular office hours, but university officials also found that the chatbot increased student motivation. All of these benefits were achieved without the need to change the structure of the staff. One additional benefit of having chatbots at universities to answer students' questions is the large volume of big data that would be obtained regarding students' concerns and areas of interest. This data could be analysed to help enable universities to create innovative new services and programs to further improve students' educational experiences.

AR will make visualization, annotation and storytelling better: Augmented Reality (AR) is a powerful visualization tool. It allows one to bring an object or concept into a reality that is otherwise imagined, inaccessible or difficult to grasp, and can even help to make the invisible visible.

\section{CONCLUSION}

Students, their parents, and educators around the world are feeling the extraordinary ripple effect of the novel coronavirus as schools are shutting down and quarantine methods are being ordered to cope with the global pandemic. While governments and health officials are doing their best slowing down the outbreak, it not only the Indian education system but also the global education systems are collaborating to collectively respond and provide quality education for all during these difficult times. While lamentable, the disruption to education systems worldwide offers valuable lessons and provides a unique opportunity to reimagine education, the curriculum, and pedagogy.

Address the digital divide: Technology has the potential to achieve universal quality education and improve learning outcomes. But in order to unleash its potential, the digital divide (and its embedded gender divide) must be addressed. Digital capabilities, the required infrastructure, and connectivity must reach the remotest and poorest communities. Access to technology and the internet is an urgent requirement in the information age. It should no longer be a luxury. 
Reorient the curriculum: While teachers are struggling to learn digital ways of communicating with their students, it is clear that we need to pay close attention to what we teach. Our endeavour to educate children has been guided by the question "Who am I and what is my relationship with the universe and others in it?" This question has taken on even greater relevance during the crisis while decontextualized academic learning and a disproportionate focus on facts and information have been downgraded. This crisis is teaching us that curricula must be grounded in students' realities, cultivating critical, creative, and flexible thinking, resilience, and empathy in students. Developing a symbiotic relationship with our environment has taken on a new urgency, and teachers must help students think about their relationship with the universe and everyone and everything in it.

SHEF has demonstrated how the development of social and political consciousness by students should be a major goal of education, and that lessons of equality and core democratic values should be given as much, if not more, importance in the official curricula than math, science, and language lessons. Now is the time for governments to integrate such a curriculum into the national curricular framework.

Empower a wider cadre of teachers: This crisis is forcing teachers to reinvent their roles from that of transferring information to enabling learning. The shift to distance learning has afforded many opportunities to teach differently, encouraging self-learning, providing opportunities to learn from diverse resources, and allowing customized learning for diverse needs through high-tech and low-tech sources.

But continuing education amid school closures has also taught us an important lesson about the role of the community in teaching our children. If it takes a village to raise a child, we must empower the village to teach the child. Improving the education system requires a decentralized, democratic community-based approach, where community ownership of education is cultivated. Important for this is the hiring of local teachers (with adequate Dalit and female representation), which increases teachers' accountability to children's families and their ability to empathize with students' lives.

If COVID-19 school closures and their related challenges with distance learning have taught us anything, it is that we must liberate learning from outdated curricula and the disproportionate emphasis on information transfer.

In this moment of crisis, digital technology holds great promise to provide learners with access to highquality learning. However, most education systems need to pay close attention that technology will not further amplify existing inequalities in access and quality of learning.

This is not just a matter of providing access to technology and open learning resources, but will also require maintaining effective social relationships between families, teachers and students, particularly for those students who lack the resilience, learning strategies or engagement to learn on their own. Technology can amplify the work of great teachers but is unlikely to replace teachers, at least for the foreseeable future.

The physical infrastructure of academic institutions will have less impact on the quality of education and thus directly on the cost of education. Review meetings, parent-teacher meetings, subject conferences will be location agnostic. The real vision of the new education policy for liberal education will get executed. It is possible that in times to come, a student may be allowed to carry out courses from any College/ University based on quality of teacher and fees for the course irrespective of his location and finally will get degree from the home university where he / she got registered or from the university where he has taken maximum courses, resulting in a balance of economics of good education.

For all this to be a reality, a drastic change in thought process is required in the mind- set of policy makers, authorities, students and specially educationists. Faculty selection should gradually be linked to technology friendliness and keenness for technology adoption. Similarly, accreditation parameters, criteria need reconsideration. All these steps will help strengthen the country's digital learning infrastructure in the long run. Covid-19 has only accelerated adoption of technologies to deliver education.

Tomorrow will be a new dawn. What we make of it is entirely in our own hands. Change is desirable; change is inevitable. Change in fact has been forced upon us. Whether we use the opportunity to advantage or let it pass us by will decide whether the future will shock us or we will create shock-absorbers that will in fact use the impact to cushion us in our journey to a better tomorrow. Perhaps, the world may never go back to what it was prepandemic. But we can count on it to adapt to the future, irrespective of what it contains.

\section{FUTURE RESEARCH}

We have attempted to highlight gaps in education system during the pandemic. Drawing from what is known and what remains less studied, we offer ideas for future research that can provide especially useful insights across this dynamic and fast-moving conceptual and practical domain. This list is by no means exhaustive, but illustrates some of the most noticeable gaps given the current state of research.

- Privacy concerns around the video conferencing application-Zoom, there are lot of allegations of data privacy leak while using Zoom application, what are the measures to tackle such issues?

- Is Artificial Intelligence the future of Management? How is it going to impact the education system?

- Challenges and Adoption strategy of new age modern education in Rural India 


\section{REFERENCES}

[1] https://www.educationcannotwait.org/covid-19/. (Retrieved on 23/05/2020).

[2] https://government.economictimes.indiatimes.com/news/ education/covid-19-pandemic-impact-and-strategies-foreducation-sector-in-india/75173099. (Retrieved on 23/05/2020).

[3] https://www.financialexpress.com/education-2/covid19-how-smart-classrooms-are-transforming-indiaseducation-system/1948670/. (Retrieved on 23/05/2020). [4] https://economictimes.indiatimes.com/blogs/etcommentary/covid-19-creating-a-paradigm-shift-inindias-education-system/. (Retrieved on 23/05/2020). [5] https://www.thehindu.com/sci-tech/technology/whyelearning-is-not-a-sustainable-solution-to-the-covid19education-crisis-in-india/article31560007.ece. (Retrieved on $23 / 05 / 2020$ ).

[6] https://voxeu.org/article/impact-covid-19-education. (Retrieved on 23/05/2020).

[7]

https://economictimes.indiatimes.com/industry/services/e ducation/government-makes-education-accessible-withpm-evidya-to-launch-dedicated-tv-

channels/articleshow/75791291.cms. (Retrieved on 24/05/2020).

[8] https://www.india.gov.in/spotlight/diksha-nationaldigital-infrastructure-teachers. (Retrieved on 24/05/2020).

[9] https://www.neweurope.eu/article/lessons-from-thecovid-19-crisis-education-disrupted-education-rebuilt/. (Retrieved on 24/05/2020).

[10] https://www.indiatoday.in/educationtoday/featurephilia/story/covid-19-lockdown-how-thepandemic-brining-change-in-indian-education-system1674322-2020-05-04. (Retrieved on 24/05/2020).

[11] https://www.brookings.edu/blog/education-plusdevelopment/2020/05/14/covid-19-in-india-educationdisrupted-and-lessons-learned/. (Retrieved on 25/05/2020).

[12] https://www.cnbctv18.com/technology/digitaleducation-during-covid-19-lockdown-not-for-all5785491.htm. (Retrieved on 24/05/2020).

[13] https://www.bbc.com/news/technology-52133349. (Retrieved on 25/05/2020).

[14] M. V. Unni. (2020 Apr). Does digital and social media marketing play a major role in consumer behaviour?. International Journal of Research in Engineering, Science and Management, 3(4), 272-278.

[15] Bjorklund, Anders \& Salvanes, Kjell G. (2011). Education and family background: Mechanisms and policies, ch. 03, pp. 201-247. In: Hanushek, Erik, Machin, Stephen and Woessmann, Ludger eds., Elsevier. Available at:

https://EconPapers.repec.org/RePEc:eee:educhp:3-03.

[16] Oreopoulos, Philip. (2006). Estimating average and local average treatment effects of education when compulsory schooling laws really matter. American Economic Review, 96(1), 152-175.

[17] Markus Nagler, Marc Piopiunik, \& Martin R. West. (2020). Weak markets, strong teachers: Recession at career start and teacher effectiveness. Journal of Labor Economics, 38(2), 453-500.

[18] Fredriksson, Peter, Lena Hensvik, \& Oskar Nordström Skans. (2018). Mismatch of talent: Evidence on match quality, entry wages, and job mobility. American Economic Review, 108(11), 33033338. DOI: $10.1257 /$ aer.20160848

[19] Oreopoulos, Philip, Till von Wachter, \& Andrew Heisz. (2012). The short- and long-term career effects of graduating in a recession. American Economic Journal: Applied Economics, 4(1), 1-29. DOI: 10.1257/app.4.1.1

[20] https://hundred.org/en/collections/quality-educationfor-all-during-coronavirus.

[21] Sengupta S. (2020). With virus surge, dermatologists and orthopedists are drafted for the E.R. New York Times. Available at:

https://www.nytimes.com/2020/04/03/nyregion/new-

yorkcoronavirus-doctors.html. (Retrieved on 25/05/2020). [22] Wanat C, Newman S, Finney KM, Kovarik CL, \& Lee I. (2016). Teledermatology education: Current use of teledermatology in US residency programs. Grad. Med. Educ., 8, 286-287.

[23] Manu Vasudevan Unni. (2020). Is robotics and artificial intelligence the future of management and economics?. International Journal of Creative Research Thoughts (IJCRT), 8(4), 2340-2345.

[24] Unni, M. V. \& Menon U, S. (2020). Does the Indian education system require a paradigm shift?. International Journal for Science and Advance Research in Technology, 6(4), 695-699.

[25] Zakaria A, Maurer T, Su G, \& Amerson E. (2019). Impact of teledermatology on the accessibility and efficiency of dermatology care in an urban safety-net hospital: A pre-post analysis. J. Am. Acad. Dermatol., 81, 1446-1452.

[26] Nicholas C. Burbules, Guorui Fan, \& Philip Repp. (2020). Five trends of education and technology in a sustainable future, Geography and Sustainability. Available at:

https://doi.org/10.1016/j.geosus.2020.05.001. 